\title{
Sociology in the German Democratic Republic
}

The Deutsche Demokratische Republik (DDR, German Democratic Republic (GDR)) was founded in 1949-the FRG had already been constituted-after World War II in the zone of Germany occupied by the Soviets. Shortly after the war, the Kommunistische Partei Deutschlands (KPD, Communist Party of Germany) and the East German branch of the Social Democratic Party (SPD) merged to form one party, the Sozialistische Einheitspartei Deutschlands (SED, Socialist Unity Party of Germany, SUPG). While in the beginning it was a rather heterogeneous party, soon it was dominated by those voices that wanted to move the party closer to the Soviet role model of the Communist Party of the Soviet Union (CPSU) (Roesler 2012, p. 25). The rapprochement with the Soviet Union was also an expression of the incipient Cold War. Moscow had initially favored the founding of a neutral Germany (Roesler 2012, pp. 16-17; Staritz 1985, p. 12), but after the conflicts over Berlin in 1948 (catchwords: Soviet blockade, Allied airlift) and the currency reform in the Western zones, it became clear that a unity of Germany was not intended, not even by the West. Consequently, although major interests of the Soviet Union played a role in the development of the GDR, the founding of the GDR on October 7, 1949, was not the result of a long-cherished plan of Moscow; rather, it has to be seen in close relation and as a reaction to the founding of the FRG and the conflicts in the incipient Cold War (Staritz 1985, p. 11; Roesler 2012, p. 28).

(C) The Author(s) 2021

S. Moebius, Sociology in Germany, Sociology Transformed, https://doi.org/10.1007/978-3-030-71866-4_5 
The SED was able to expand its power rapidly. From 1950 it was headed by Walter Ulbricht (1893-1973), who became General Secretary of the party that year. The aim of the party was to build up socialism. Marxism-Leninism was to be imposed as the leading worldview. Ideologically it was sought to take action against all possible "capitalist elements." In different ways, this affected art and culture too. For example, 1949 Bertolt Brecht and Helene Weigel founded the Berliner Ensemble, a German theatre company which even had a great impact in the West. It was also well attended by workers. Another, different example of the ideological effect on art was that artists turned away from the abstract art of the West and proclaimed Socialist Realism.

Already four years after the foundation of the GDR, on June 17, 1953, an uprising took place (Roesler 2012, p. 36) which could not be prevented, not even by the propaganda of a "new course" that was to be taken after Stalin's death in 1953. The starting point for the uprising in June 1953 was the economic difficulties of the GDR. Among other things, the GDR leadership had decided to raise worker norms, so that the workers had to work $10 \%$ more for the same wage (Wolfrum 2008, p. 14). This led to immense discontent among the workers. At first, construction workers protested and went on strike against the increase of the working standards. The protests soon expanded and eventually became protests against the SED regime in general. There were nationwide strikes and demonstrations. The SED leadership finally called on the Soviet military for help. The uprising was suppressed with military force. June 17, 1953, engraved itself deeply in the collective consciousness of the GDR citizens as well as into that of the GDR leadership. The citizens were then increasingly intimidated and the leadership expanded its apparatus of repression and control. They avoided an all too sharp confrontation with the population and relied on "more subtle mechanisms of surveillance" (Mählert 2009, p. 78).

State repression reached a further peak in 1961, when over three million people had already left the GDR. The FRG became increasingly threatening to the existence of the GDR, as life in the West seemed much more attractive thanks to the Wirtschaftswunder (economic miracle) of the 1950s. When in 1960 the economy in the GDR started to slow down and a shortage of supplies led to a crisis, the number of refugees from the GDR to the FRG increased enormously: "At the beginning of 1961, an average of 19,000 people left each month" (Wolfrum 2008, p. 15). The leaders of the SED reacted by building the Berlin Wall, beginning on August 13,1961 . 
The years after 1961 were marked by "reforms and modernization" (Malycha 2011, p. 37; see also Sywottek 2003): In 1962, for example, general conscription was introduced, and in 1963 the "New Economic System" was implemented, by means of which it was hoped that the economy would be modernized toward profit orientation. The "planned economy" and the market were to be combined. The reform was associated with a certain opening and led to a general "spirit of optimism" (Roesler 2012 , pp. 58-62), also in the arts and literature. Some believed that once it had been proven that the GDR was superior to the capitalist West, the Wall would be unnecessary. Although the growth in productivity was very slow, the supply with consumer goods such as television sets, refrigerators, and washing machines increased. The demand for consumer goods such as cars was intense, so that there were waiting periods of several years. Television in particular, however, would prove to be a boomerang (Lehmann 2019). Many people in the GDR had secret access to Western TV channels. Now the citizens could directly compare the developments in the GDR with those in the West, or at least with what the culture industry there conveyed as Western reality. Over time, this led to frustration and a subtle renunciation of the socialist project.

Within the political elite, a conservative circle formed that strongly opposed the reform and the "ideological blurring" (Roesler 2012, p. 65), among them the later Secretary General Erich Honecker (1912-1994). Ulbricht made concessions to the conservatives in the areas of culture and youth, but not in the area of economics, where the reform programs should continue to be maintained. There were also reforms of the universities, which in fact brought less of an opening but, rather, more centralization. As we shall see, sociology was also centralized through a Scientific Council for Sociological Research.

The academic personnel also changed in the years after 1945, and the proportion of professors who had a family background in the educated middle classes decreased significantly over the years. People from other classes were now also able to enter the educational sector. For a certain time, students were selected according to social and political criteria, children of workers and farmers were advantaged in the admissions to universities.

The natural sciences, in particular, were funded and closely linked to the economy. This was related to the ideology of the "scientific and technological revolution" propagated by the SED, which came about as a result of the rapid developments in science and technology (Malycha 
2011, p. 41). One of these developments could be seen in the field of space research: Yuri Gagarin's 1961 space flight had caused euphoria in the entire Eastern Bloc and fueled technological visions of the future. Science was regarded as an important productive force and it "should deliver technical innovations for the modernization of the economy" (Malycha 2011, p. 41). However, science could not deliver as quickly as had been hoped for and research was far more expensive than politicians thought. Already in the early 1970s "resources for science were increasingly being cut and invested in social policy" instead (Malycha 2011, p. 42).

When Soviet tanks put down the "Prague Spring" at the end of 1968, a lot of people in the GDR lost hope that socialism could be reformed. While the reform of the economy had initially had a positive effect on living standards, in the end the reform did not produce the desired results. At the end of the 1960s economic problems arose that were also related to those in the Soviet Union (Malycha 2011, p. 47). This led to an economic crisis in the GDR and to "reform fatigue and resignation" (Roesler 2012 , p. 69) among the population. The Politburo of the Central Committee became increasingly critical of Ulbricht's plans for modernization. The course of Ulbricht's rapprochement with the social-liberal coalition of Chancellor Willy Brandt in West Germany was also heavily criticized by conservative circles (Malycha 2011, p. 48). Finally, on May 3, 1971, Ulbricht was overthrown by Erich Honecker and his circle of reform critics.

In 1971, the SED decided on the "unity of economic and social policy." This led to numerous subsidies, increases in salaries, and the financing of social projects, while at the same time reducing investment in research. At the beginning of the 1970s, the GDR experienced a brief economic upswing that it owed to those measures that had been taken by Ulbricht (Roesler 2012, p. 75). Therefore, the years 1970-1975 have often been described as the best in the GDR. Various modernization measures as well as the admission to the UN took place during these years (Wolfrum 2008, p. 16).

However, similar to the FRG, the oil crisis in the mid-1970s plunged the GDR, too, into a crisis. Debt continued to rise, but initially very few people were aware of this (Roesler 2012, p. 84). Repression also increased. The Ministry of State Security (Ministerium für Staatssicherheit, commonly known as Stasi), the secret police and intelligence agency of the GDR, established in 1950, was massively expanded in the 1970s (Roesler 2012 , p. 80). Discontent among the population grew as it became 
increasingly obvious that the promises and expectations raised by Honecker would not be fulfilled (Wolfrum 2008, p. 75). In the 1980s opposition groups emerged, especially environmental, church and peace groups. However, these were not fundamentally opposed to a socialist system; rather, they hoped for a different kind of socialism (Roesler 2012, p. 94). Mikhail Gorbachev further nurtured hopes for such a change.

When the border between Hungary and Austria was torn down in May 1989, a wave of emigration began. In Prague, citizens of the GDR occupied the embassy of the FRG. In autumn 1989 there were mass protests. The GDR was in a deep crisis. Even the GDR leadership noticed this. In October, Erich Honecker finally had to resign. The secretary of the Central Committee, Günter Schabowski, presented new travel regulations at a press conference on November 9, 1989, including visa-free travel to the FRG, and in a moment of obvious overstrain and insecurity at the press conference he declared that these were effective immediately. In a moment, thousands headed for the border crossings and finally arrived in West Berlin. The Wall fell. One year later, the GDR no longer existed. In 1990 it became (via "Beitritt") part of the Federal Republic of Germany.

\section{"SOCIOLOGY - IS THAT REALLY NECESSARY? WE HAVE EXCELLENT STATISTICS, EXCELLENT STATISTICS!"}

At a meeting of the Politburo in 1964, Erich Honecker, who was then still Walter Ulbricht's deputy, questioned: "Sociology-is that really necessary? Yet, we have an excellent statistics, excellent statistics!" (quoted from Sparschuh and Koch 1997, p. 88). Despite this skepticism, sociology was able to establish itself in the GDR and was even officially institutionalized in the same year, 1964. How did this come about?

The development of sociological research in the GDR is embedded in the larger process of social reorganization in the Soviet-occupied zone after 1945. The ideological class struggle was not limited to the political field; in fact, it affected academia too. The universities were undergoing a massive transformation. Besides the early denazification measures, efforts were made to make universities accessible for all social classes. A central concern was the distancing from "bourgeois" Western conceptions of science, which reached as far as into the development of theories, methods, and research strategies (Peter 2018, p. 388). Therefore, it was difficult to tie in with the thinking of early proponents of sociology. The ideological guideline was Marxism-Leninism. 
As Frank Ettrich, sociologist from the GDR and now professor in Erfurt, has pointed out, sociology in the GDR can be divided into three phases (Ettrich 1997, pp. 272-292; Sparschuh and Koch 1997, p. 106): The first phase is characterized by the fact that the remnants of "bourgeois" sociology gradually disappeared. In the second phase, sociology re-institutionalized itself in the system of Marxist-Leninist social sciences and a "Marxist-Leninist sociology" emerged. In the third phase, MarxistLeninist sociology became normal science (Kuhn) and empirical research dominated. Only in the 1980s did a "quest for new approaches" and "a new reflection on the sociological heritage" begin (Steiner 1997, p. 225).

\section{Separation from “Bourgeois” Sociology}

In the first phase of sociology in the Soviet-occupied zone there were certain continuities with Weimar sociology (see Chap. 2). Scholars from the Weimar Republic, such as Theodor Litt or Hans Freyer, who was engaged with the Nazis, were still teaching in Leipzig. But they left the GDR fairly quickly. Richard Thurnwald and Alfred Vierkandt, among others, taught at the Humboldt University in Berlin. Thurnwald quickly moved to the West, to the Free University of Berlin, and Vierkandt retired. Also at Humboldt University were Alfred Meusel (1896-1960), a former disciple of Tönnies, and Jürgen Kuczynski (1904-1997), who both had returned from exile. Others, who had come to the GDR on purpose and in hope of a new society, such as Heinz Maus, turned away with disappointment from the GDR after a few years (Peter 2018, p. 389). However, a look at the course lists at that time reveals that after 1945 all universities offered a large number of sociological courses (Steiner 1988, p. 79). These covered topics ranging from the sociology of law to the position of women in society. Sociological essays were published as well. And sociology was also taught in other disciplines (Meyer 1992, p. 263).

After the founding of the state in 1949, however, a stronger separation from Western sociology, which was described as "bourgeois" (Thomas 1990 , p. 2), began, which was often equated with a critique of sociology as a whole (Steiner 1988, p. 87). The Frankfurt School, too, was criticized for offering a "bourgeois critique" and therefore for being "theoretically misoriented" (Dieter Ulle quoted by Rust 1973, p. 149). But since sociology itself did not propose any alternative, such as an independent Marxist sociology, and a university reform in 1952 made Marxist-Leninist studies compulsory for all, sociology came to its "institutional end" (Ettrich 
1997, p. 275). Instead, political economy, materialistic philosophy, and Marxism-Leninism, as a kind of "science of society" (as, e.g., in the form of "scientific communism"), were now dominating the interpretation and explanation of social processes (Meyer 1992, p. 264).

\section{The Institutionalization of Marxist-Leninist Sociology}

In the mid-1950s, the first impulses for a "new development in sociology" emerged from philosophy and political economy (Sparschuh and Koch 1997, p. 60). The reform policies of Nikita Khrushchev (1894-1971), his critique of Stalin, and the "vision of a scientific and technological revolution" fostered these new developments (Meyer 1992, p. 265). When at the end of the 1950s "a new type of social thinking" appeared in the Eastern Bloc (Meyer 1994, p. 36, English in original), the academic system also began to open up for new disciplines and a slow process of differentiation of academic disciplines began. "[A]lso the idea of instigating empirically oriented social research arose" and social research was equated with sociology (Meyer 1994, p. 36, English in original). Through this differentiation, the individual disciplines, such as sociology, "were relieved of the demands of Marxist-Leninist philosophy to such an extent that they could now establish themselves as separate empirical disciplines, albeit with the condition that they be founded as Marxist-Leninist disciplines" (Ettrich 1997, p. 276).

Sociology was able to evolve as a distinct discipline, but it was not fully independent, because it still stood under "the curatorship of MarxistLeninist ideology" (Peter 2018, p. 389). Furthermore, it was to serve only the implementation and consolidation of the socialist state. The MarxistLeninist sociology that emerged from this was basically structured in such a way that it incorporated the empirical methods of "bourgeois" sociology, applied the results to social technology and technocratic reforms, and finally expressed all this in terms of Marxism-Leninism (Ettrich 1997, p. 277). From now on, Marxist-Leninist scientists of society (Gesellschafts wissenschaftler*innen) and Marxist-Leninist sociologists, the latter being reproached for the adoption of "bourgeois" sociology, stood in opposition to each other (Meyer 1992, p. 264). Sociology could only defend itself by emphasizing the need for empirical social research (Kaube 1998, p. 275) and by offering itself as a "service discipline for social progress" 
(Kaube 1998, p. 276), an argument that Marxist-Leninist social scientists had difficulty arguing against, since Marx and Engels had already pointed out the usefulness of empirical research (Meyer 1992, pp. 264-265). In the course of the attempts to implement the "scientific-technical revolution" by means of empirical social research, with which sociology tried to establish itself, there were certainly "parallels" to sociology in West Germany (see Chap. 3), which at that time also saw itself as an important means of social technology, prognosis, and "planning knowledge" (Kaube 1998, p. 274). However, while sociology in West Germany soon turned back to the formation of theories, this could not be done to the same extent in the GDR (Kaube 1998, p. 277), because sociology in the GDR had to limit itself to empirical research-theory already existed in the sense of historical materialism.

The new beginning of sociology in the GDR was particularly visible at the universities of Leipzig, Berlin, Rostock, Merseburg, and Halle (Meyer 1992, pp. 268-269; Pasternack 2013). Scholars of the founding generation of GDR sociology mostly came from the fields of economics and philosophy, among them Robert Schulz (1914-2000) (Leipzig) and Herbert Franz Wolf (1927-1993) (Leipzig), Kurt Braunreuther (1913-1975) (Berlin), Hermann Scheler (1911-1972) (Berlin), and Jürgen Kuczynski (Berlin).

Robert Schulz, for example, taught sociology from 1954 onwards and dealt with the history of sociology as well as with French and US-American sociology. In 1956, together with Hermann Scheler, Schulz headed a delegation to the ISA World Congress in Amsterdam (Sparschuh and Koch 1997, p. 42), where he also met René König, who supported the GDR sociologists and tried to integrate them into the international community. Schulz set up a sociological research group and pursued industrial sociology. Industrial sociology was initially one of the preferred topics of sociology in the GDR (Meyer 1992, pp. 269-270), since industry was considered to be of particular relevance not only for economic development, but also for ideological reasons, as the "basic type of the new social relations of the leading class of workers" was to be found there (Meyer 1992, p. 269). In addition, since the end of the 1950s there had also been research in the field of sociology of youth in Leipzig, which was intensified in 1966 with the founding of the Zentralinstitut für Jugendforschung (ZIJ) (Central Institute for Youth Research).

From 1956 onwards, Kurt Braunreuther also dealt with sociology in his seminars on the history of economics. He founded a working group on 
the "critique of bourgeois sociology," from which the Research Association for Sociology and Society (Forschungsgemeinschaft für Soziologie und Gesellschaft) emerged in 1961 (Meyer 1994, p. 36, English in original). In this research association Helmut Steiner, Georg Aßmann, Manfred Lötsch, Siegfried Ransch, and others discussed West German sociology. Günther Rudolph (1929-2017), who was studying the work of Tönnies, also belonged to the circle around Braunreuther. The discussion of leading Western German sociologists resulted in rather voluminous dissertations: Herbert Wolf wrote (1963) about the Formale Soziologie by Leopold von Wiese, Georg Aßmann (1965) about Schelsky as an apologist of West German imperialism, Günther Rudolph about Tönnies (1966), and since 1962 Braunreuther and Steiner focused on fascist tendencies in several sociological works (Freyer, Ipsen, Höhn, Pfeffer, Schelsky, Müller).

In 1961, the same year the Berlin Wall was built, the Sektion Soziologie der Vereinigung der philosophischen Institutionen der DDR (Section for Sociology of the Association of the Philosophical Institutions of the GDR) was founded, which became the national representation of the GDR sociologies in the ISA starting from 1963 (Ettrich 1997, p. 277). ${ }^{1}$ The chairman was Hermann Scheler. In 1958, he published the book Probleme des historischen Materialismus und der marxistischen Sozialforschung (Problems of Historical Materialism and Marxist Social Research), which is seen by some as "the first sociological document of the GDR" (Sparschuh and Koch 1997, p. 67).

Sociology experienced an important boost in 1963. The political background of this boost was "the turn towards a technocratic socialism" (Thomas 1990, p. 3). It was hoped that sociology would provide support for the political leadership of the party and the state. At the VI Party Congress of the SED, it was therefore stated in the party program that sociological research should be intensified. In addition, efforts were made to centralize sociology. Against the background of this political decision, sociology was finally officially institutionalized in 1964. A department was established at the Institute for Economic Sciences at the German Academy of Sciences in Berlin, with Helmut Steiner, Manfred Thiel, Rainer Schubert, Manfred Lötsch, and Hansgünter Meyer, working on industry, organization, labor, and social structure (Meyer 1994, pp. 36-37). Braunreuther became a member of the Scientific Council for Sociological

\footnotetext{
${ }^{1}$ On the process of institutionalization see the overview in Sparschuh and Koch (1997, pp. 273-287).
} 
Research in the German Democratic Republic, founded in 1964. The founding of this Council was based on a decision of the Politburo of the Central Committee (CC) of the SED. The chairman of the Council from 1968-1971 was Erich Hahn (*1930), and from 1972-1989 it was Rudi Weidig (1931-2012) (Weidig 1997, Sparschuh and Koch 1997, p. 53, footnote 34). The Scientific Council was located at the Department for Sociological Research at the Institut für Gesellschaftswissenschaften (IfG) (Institute for Social Sciences) at the SED CC (Weidig 1997, p. 61). ${ }^{2}$ The scholars were ambivalent about the Council. They perceived it "as a disciplining body on the one hand, and as a protective shield for the discipline against political intervention on the other" (Sparschuh and Koch 1997, p. 93).

The SED now increasingly demanded and supported sociological research, hoping that it would be of use for the political leadership and for political planning. Unlike in the West, however, the institutionalization that now took place did not mean an increase in autonomy. Rather, as Frank Ettrich emphasizes, the institutionalization of sociology served the purpose of instrumentalizing sociology for the requirements of preserving the system. Sociology was now "within the party, officially the 'science of the management and development of society" (Ettrich 1997, p. 278). Two complementary positions could be observed in the sociological field. One was oriented more toward the technocratic guidelines of the SED for the "objectivization of social planning," the other followed the guiding idea and research of the "socialist human community" and sought to prove that the "scientific-technical revolution would lead to the socialist human community" (Ettrich 1997, pp. 281-282).

Despite or perhaps because of the control and orientation toward the party, there was an "upswing in sociology" (Sparschuh and Koch 1997, p. 71). This initially concerned empirical research. But also studying: Since the mid-1960s, students of an economics or philosophy major could choose sociology as a minor. However, there was no full-fledged sociology program until 1975 (Meyer 1994, p. 38; Kaube 1998, p. 268). By 1989 there were 600 graduates with a sociology diploma (Meyer 1994, p. 38 ). There was also a small "boom" in institutionalization in the form of congresses: From 1969 onwards, the Scientific Council organized congresses; altogether they organized five major congresses, one about every five

\footnotetext{
${ }^{2}$ In the mid-1970s, the Institute for Social Sciences at the SED CC became the Academy for the Social Sciences at the SED CC.
} 
years. However, other important elements of successful institutionalization were missing: The establishment of a separate association or journal was not permitted. This was justified by the fact that sociologists could publish in the Deutsche Zeitschrift für Philosophie or in one of the journals of the economists (Sparschuh and Koch 1997, p. 88). However, research results could also be published in the periodical of the Scientific Council Information on Sociological Research in the German Democratic Republic" (Thomas 1990, p. 5). In addition, there was a publication series titled "Sociology" of the party publisher Dietz. It was not until the 5 th Congress in 1990 that an independent Gesellschaft für Soziologie der DDR (GFS) (Society for Sociology of the GDR) was established and the Berlin Journal of Sociology (Berliner Journal für Soziologie), edited by Manfred Lötsch (1936-1993), Artur Meier (*1932), Hansgünter Meyer (1929-2015), Peter Voigt (1939-2014), and Herbert F. Wolf, was published, with Frank Ettrich $\left({ }^{*} 1958\right)$ as editor-in-chief (Meyer 1994, p. 39). These processes took place immediately after the collapse of the GDR.

\section{MarXist-Leninist Sociology on Its Way TO A Normal SCIENCE?}

Many sociologists perceived the period up to the transfer of power from Ulbricht to Honecker in 1971 as the "productive phase" of sociology in the GDR (Sparschuh and Koch 1997, p. 108). An indication of the gradual consolidation and canonization was the publication of the Wörterbuch der marxistisch-leninistischen Soziologie (Dictionary of Marxist-Leninist Sociology) in 1969 and the textbook Grundlagen der marxistischleninistischen Soziologie (Principles of Marxist-Leninist Sociology) in 1977, but this canonization was at the same time also perceived as "normalization" (Sparschuh and Koch 1997, pp. 108-109). The hope was that empirical social research could be conducted under the theoretical framework of historical materialism. However, as Thomas (1990, p. 20) has pointed out, social research was also increasingly subject to "control measures," such as bans on publications or interventions in the design of empirical research.

While the main focus of sociology in the GDR until the end of the 1960s was on industrial sociology, the sociology of labor, sociology of organizations, sociology of agriculture, sociology of culture, sociology of education and youth, as well as the development of personality ( $\mathrm{Ludz}$ 
1972a, 1972b; Wittich and Taubert 1970), it continued to differentiate itself in the following years (Hamm 1989, p. 142). In addition, there were social policy research, demography, sociology of science, of medicine, of religion, of development, sociolinguistics, research on mass communication, urban sociology, and sociology of sports (Meyer 1992, pp. 268-269; 1994, pp. 40-46; Kaube 1998, pp. 286-290).

As of the 1970s, analyses of social structure and social change became central topics (Thomas 1990, p. 7). It had become apparent that the social reality of the "socialist human community" was more complex and differentiated than expected and that social policy measures had to be tailored to the specific situation. For this reason, research on social structure was closely related to the party's efforts to achieve a "unity of economic and social policy" and an "alignment of other classes and strata with the working class" (Ettrich 1997, p. 287). Sociology was to accompany and legitimize the policies of the SED. This led to a "re-actualization of the class theorem" (Peter 2018, p. 400), to an increased revaluation of the working class and to the view that there were also differentiations within the working class. In accordance with the focus on social and political planning, the second Sociological Congress in 1974 was devoted to the "Contribution of Marxist-Leninist sociology to the management and planning of social processes in the shaping of the developed socialist society."

Although sociology was actually supposed to serve the legitimation of the state, it simultaneously unfolded, "even in its crudest empirical form, a force that was delegitimizing ideological normativity" (Ettrich 1997, p. 289). For example, sociological research revealed that it was not the working class but the class of white-collar workers that was growing, and that not a proletarian but, rather, a petty-bourgeois white-collar worker habitus prevailed. Nevertheless, the phase of the 1970s was marked by system adjustment and self-censorship. This often led to results that conformed to the system and to highly speculative forecasts. For example, indications were seen that the two classes of "workers and peasants" and the class of scientific-technical intelligentsia would merge (Peter 2018, pp. 400-401). This idea of levelling correlated with the assumption that society is a coherent, uniform organism - that the "socialist society was a [...] uniform entity" (Kaube 1998, pp. 263-264). As Jürgen Kaube has pointed out, sociologists in the GDR saw themselves as a functional component of this "organic solidarity" (Durkheim), as "part of a society based on the division of labor" (Kaube 1998, p. 263). 
Often the sociologists focused on the possibilities of political application of their results in order to justify their research (Thomas 1990, p. 9). "Since the methods and techniques of empirical research were adapted to the state's monopoly of political planning, they could thus only sporadically contribute to findings in which a critical processing of social processes and relationships manifested itself" (Peter 2018, p. 398). If the results did not fit into the political concept, they were kept secret; the researchers were disciplined or dismissed (Meyer 1992, p. 271). For example, in 1978 the Institute for Opinion Research at the SED CC was closed down. Honecker justified this by arguing that the surveys should not fall into the hands of the "class enemy" - "the reasoning allows the conclusion that the results of the survey research had turned out to be less favorable for the politics of the SED than the General Secretary had expected" (Thomas 1990, p. 19).

In 1980, the "concept of the socialist way of life" moved into the center of sociological attention (Thomas 1990, p. 18). It was intended as an alternative approach to "the research on the 'standard of living', 'quality of life' or 'lifestyle' that began in the FRG in the 1960s" (Kaube 1998, p. 289). The third Sociological Congress was dedicated to the topic "Social structure and way of life in shaping the developed socialist society." Sociologists tried to develop social indicators and to make them useful for the planning of society. In particular, the Institute for Sociology and Social Policy, founded in 1978 at the Academy of the Sciences and headed by Gunnar Winkler (1931-2019), was leading in this field (Thomas 1990, p. 18; Kaube 1998, pp. 267-268).

At the beginning of the 1980s, it was especially Manfred Lötsch, Rudi Weidig, Frank Adler, Albrecht Kretzschmar, and Ingrid Lötsch who criticized the theorem of the convergence of classes and the notion of social homogeneity (Thomas 1990, p. 21; Peter 2018, pp. 401-402). According to them, the social processes of differentiation that were also noticeable in the GDR as well as the inequalities between the working class and the class of the scientific-technical intelligentsia were not to be denied but to be used productively. On the basis of a study of engineers in the GDR, as a group belonging to the class of scientific-technical intelligentsia, it could be shown that this group could only play a central role in the process of modernization if its specific social position and status characteristics were acknowledged. The analyses of Lötsch et al. (1988) gave rise to debates. These analyses were agreed upon by most sociologists but not used for political practice (Thomas 1990, p. 21). Innovation by sociologists was 
neither expected nor desired; critical findings were kept secret. The state was satisfied-if at all-if sociologists stuck to their role of "sociotechnological assistants" (Thomas 1990, p. 21).

The change in the 1980s toward more critical tones was, among other things, the result of a change of generations (Sparschuh and Koch 1997, p. 112; Kaube 1998, p. 292), of increasing professionalization, and of the general transformation in the Eastern Bloc (perestroika and glasnost) (Sparschuh and Koch 1997, p. 106). In 1988, at the joint Soziologentag of the Swiss, Austrian, and German Sociological Associations in Zurich, further official exchanges with the West took place when "the first official delegation of East German sociologists" took part (Meyer 1994, p. 34, English in original). The 1980s saw a further relative expansion and pluralization of the fields of research. In addition to social structure, demography, change in values, sociology of work, youth, family, and urban sociology, there was now an increasing amount of research on crime, war and peace, family, leisure, the environment, and on the role of women in society (Meyer 1994, pp. 40-46).

However, women's studies had a particularly difficult position because, according to the ideology under socialism, there was no discrimination against women. The reality was of course different (Adler and Kretzschmar 1993; Kaminsky 2020). Even male colleagues in sociology sometimes polemically distanced themselves from feminist positions. Although there had previously been research on the position of women, the inequalities between men and women were always regarded as a so-called "side contradiction" which would dissolve automatically once the social antagonisms between the classes had disappeared; or, women's studies were "ridiculed as a hobby" (Dölling 1993). In contrast to sociology in West Germany, where gender was considered a central category of social structure by then, the "women's question" was subordinated to the "social question." "The possibility that gender relations could be an independent social structural category that did not merge with the relations of production, let alone be the determining structural element of modern societies in general, was persistently denied, not even admitted as a debatable research question" (Peter 2018, p. 405). This only changed in the 1980s with researchers such as Hildegard Maria Nickel ( * 1948) or Irene Dölling who were also important for the reception of Bourdieu in the unified Germany. Influenced by Bourdieu, by Symbolic Interactionism, Structuralism, and Feminist Marxism, Dölling and other female researchers in the GDR were interested in the "cultural constructions of femininity 
and masculinity, their concrete manifestations, for example in literature or the visual arts, and their role in establishing and stabilizing relationships of power and domination" (Dölling 1993, p. 400; 2006).

\section{The Characteristics and Role of Sociology IN THE GDR}

What were the characteristics of sociology in the GDR? Sociologists from the GDR characterized them in "terms of sources" as "German three times over": firstly, through its relation to Karl Marx and the classical German philosophy incorporated in his work, "secondly through its dependence on the classical bases of German sociology, and finally through its incessant efforts to attain the professional format of West German sociological practice" (Meyer 1994, p. 34, English in original). Frank Ettrich (1997, p. 272) considers the following to be the peculiar characteristic of sociology in the GDR: It wanted to follow the "universalistic rules of science" and, at the same time, the "particularistic demands of the political system." According to Kaube, another "dilemma of sociology in the GDR" was that sociology saw its function in the orientation toward social problems, but politics had little interest in "taking on this service function" (Kaube 1998, pp. 276-277).

As for the specific role that sociology played in the GDR, referring to Lothar Peter (2018, pp. 413-415), the following points can be made: Firstly, sociology played "no orienting intellectual role" in the transformation processes around 1989. It was predominantly conformist with the system and, if at all, it tended to make cautious proposals for reform. It was therefore far from being a kind of critical discipline. This was not only due to pressure from the state, but also to a dogmatic interpretation and application of the work of Marx and Engels. Secondly, in its "fixation on social laws and regularities," sociology could not turn its attention to those social processes, events, and structural changes that did not follow regularities. Even if one can find parts of such thinking in Marxism, at the same time this contradicted that part in Marx and Engels that assumes a historicity of everything that has to do with society. Thirdly, despite all that, sociological approaches developed which had a "relatively independent profile." By this, Lothar Peter refers in particular to those analyses that turned to empirical reality. These approaches tried, so to speak, to dissolve the connection between the base and the superstructure "from 
below" (Peter 2018, p. 415). Although extremely productive, however, even these approaches did not succeed in "breaking through the established paradigm of Marxism-Leninism and in developing a qualitatively new, independent form of critical sociological analysis" (Peter 2018, p. 415). Fourthly, GDR sociology was always under the "guardianship of economics and philosophy," and fifthly, it largely detached itself from the international discourse. Sociology in the GDR was limited exclusively to "the presence of its own state" (Kaube 1998, p. 283).

It was only during the final years of the GDR that one could observe hopeful signs of an opening and renewal. In 1990, at the 5th Congress of GDR Sociology, the Gesellschaft für Soziologie was founded (Schäfers 2016) in the hope that GDR sociology would become an equal partner of West German sociology (Lepsius 2017h, p. 334). It would also have been interesting to see what view of West Germany GDR sociology would have developed. But by then it was already too late. After the reunification at the beginning of the 1990s, sociology in the GDR was "completely wound up" (Kaube 1998, p. 297) and the elaboration of an independent Marxist or critical sociology was thus denied. Many researchers were dismissed; sociology was reorganized from the West. A considerable number of sociologists from West Germany have been offered positions at universities in the East. They have thus benefited from the "winding-up" of the universities in the East and assumed the power of definition of "good" sociology.

In addition, as Jürgen Kaube (1998, p. 271) points out, in contrast to sociology in West Germany, there was no real formation of different, opposing "schools" in the GDR sociology. If one follows Kaube (1998, p. 271), however, it is precisely the internal controversies, conflicts, and competitive situations that not only produce new knowledge and innovations, but also give academic disciplines their structure (cf. Kneer and Moebius 2010). This is another reason why a "unified science", as some sociologists are now demanding in Germany, is not desirable. Sociology in the GDR understood itself, analogous to the ideology of its social model, as a conflict-free entity. GDR sociology "externalized" conflict and competition; there was competition only in the "external relationship of the social sciences to the 'bourgeois class'," but this external competition was not sufficient, because it "did not have a structure-building effect internally” (Kaube 1998, p. 271). 
Open Access This chapter is licensed under the terms of the Creative Commons Attribution 4.0 International License (http://creativecommons.org/licenses/ by $/ 4.0 /$ ), which permits use, sharing, adaptation, distribution and reproduction in any medium or format, as long as you give appropriate credit to the original author(s) and the source, provide a link to the Creative Commons licence and indicate if changes were made.

The images or other third party material in this chapter are included in the chapter's Creative Commons licence, unless indicated otherwise in a credit line to the material. If material is not included in the chapter's Creative Commons licence and your intended use is not permitted by statutory regulation or exceeds the permitted use, you will need to obtain permission directly from the copyright holder. 